\title{
KLRG1 Gene
}

National Cancer Institute

\section{Source}

National Cancer Institute. KLRG1 Gene. NCI Thesaurus. Code C123853.

This gene plays a role in the inhibition of cytotoxic immune cells. 